\title{
Chemical Composition of the Cashew Apple Bagasse and Potential Use for Ethanol Production
}

\author{
Flávia Cristina dos Santos Lima ${ }^{1}$, Flávio Luiz Honorato da Silva², Josivanda Palmeira Gomes ${ }^{3}$, \\ José Mariano da Silva Neto ${ }^{1}$ \\ ${ }^{1}$ Department of Chemical Engineering, Center of Sciences and Technology, Federal University of Campina Grande, \\ Campina Grande, Brazil \\ ${ }^{2}$ Department of Chemical Engineering, Center of Technology, Federal University of Paraiba, João Pessoa, Brazil \\ ${ }^{3}$ Department of Agricultural Engineering, Center of Science and Technology, Federal University of Campina Grande, \\ Campina Grande, Brazil \\ Email: flavia.c.7@hotmail.com, flavioluizh@yahoo.com.br, josivanda@gmail.com,neto-silva@hotmail.com
}

Received August 23, 2012; revised September 25, 2012; accepted October 5, 2012

\begin{abstract}
On the world scene, the energy requirements are mainly based on fossil fuels, however, these compounds reserves are finite and their exploitation has caused serious environmental problems. As a consequence, the demand for alternative renewable sources has been intensified in substitution the rising demand for energy and raw materials. The biomass is emerging as one of the few sources that have potential to meet these challenges of sustainability, as is currently the largest energy resource in the world, and only carbon-rich material available on the planet, apart from fossils. Form, the cashew crop has great potential for technological development of alternative sources of energy, from its industrial waste processing cashew adding value to the product. In this sense, this paper aims to study the characterization of the cashew apple bagasse and to verify (by acid prehydrolysis) the potential of this material for ethanol production. Initially it was carried out physicochemical characterization of cashew bagasse used $(\mathrm{pH}$, moisture content, soluble solids, sugars, cellulose, hemicellulose and lignin). Following it was carried prehydrolysis at $105^{\circ} \mathrm{C}$ for $1 \mathrm{~h}$ to obtain fermentable sugars. Analyses of the samples were carried out on HPLC the results showed the saccharification of biomass with glucose $(1537.49 \mathrm{mg} / \mathrm{L})$, xylose $(3823.22 \mathrm{mg} / \mathrm{L})$ and arabinose $(7131.11 \mathrm{mg} / \mathrm{L})$ as well as the capacity of the biomass for ethanol production.
\end{abstract}

Keywords: Pre-Hydrolyze; Ethanol; Cashew Apple Bagasse

\section{Introduction}

The world's energy needs are based on fossil fuels, however, the impending shortage of fossil oil and environmental problems that its holding concerned, it has aroused in the scientific community interest in new alternative energy sources renewable and sustainable [1,2]. In this context, the biomass comes as one of the sources having this potential, because when produced sustainably, can dramatically reduce emissions of greenhouse gases compared to fossil fuels, as the only carbon-rich material available on the planet $[3,4]$, which can be used for energy, heat, liquid and gaseous fuels, and also serves as a raw material for chemicals and materials.

Brazil is enjoying a comfortable position in the world with the technology of ethanol production. In this sector, the United States is currently the largest producer, except that the bioethanol produced from corn (cost three times higher than derived from cane sugar), followed by Brazil which uses cane sugar, with an ethanol production of
27.7 billion liters, respectively, in the harvest of 2008/ 2009 [5].

The lignocellulosic biomass represent an abundant source of sugars by biotechnological processes can be converted to products of industrial interest such as ethanol. This biofuel is currently produced from virtually raw beet and starch, cane sugar and maize, respectively. However, researchers are developing new processes for the most economically viable use of the component of lignocellulosic biomass such as agricultural residues (straw and bagasse of sugar cane, wheat straw and corn stover) and forest residues (dust and waste wood), for production of fuel ethanol (second generation ethanol) [6,7].

In Brazil, the cashew nut harvest (2008/2009) accounted for $11 \%$ of world production, which represents more than 6 million tons of cashew [8]. However, in the Northeast, cashew agroindustry has an outstanding role in the local economy, because, in industrial processes $40 \%(\mathrm{w} / \mathrm{w})$ of bagasse is normally discarded by the in- 
dustry [9]. So sustainably this culture has great potential for technological development of alternative energy sources, from their industrial waste processing, besides being used as a support for cells in alcoholic fermentation of juice cashew [10].

The cashew bagasse is a lignocellulosic waste that is composed mainly of cellulose, hemicellulose and lignin. For these residues are bioconverted it is necessary to subject them to physical pretreatments and/or chemicals prior to hydrolysis in order to produce ethanol. Such pretreatment aimed at removing lignin and hemicellulose, reducing the crystallinity of the cellulose and increasing the porosity of these materials so as to make the pulp more susceptible to hydrolysis. Among the various options for pre-treatment, the use of dilute acid in addition to removing the selective hemicellulose produces liqueurs (prehydrolysis) with high content of pentoses and reduced lignin content $[8,11]$.

This liquor resulting from the pre-hydrolysis is constituted by compounds such as pentoses (xylose and arabinose) at high concentrations and hexoses (glucose, mannose, galactose, etc.) components of the hemicellulose. During the pretreatment the acids used as catalysts in the process release protons that act on glycosidic bonds between the monomers polymeric sugar chains, causing the breaking of these bonds releasing a number of undesirable compounds in the fermentation process, leading to partial degradation of pentoses and hexoses, generating furfural and 5-hydroxymethylfurfural (5-HMF) [12].

In this context, this work was to study the characterization of the cashew apple pomace and by acid hydrolysis pre-determine their potential for ethanol production.

\section{Materials and Methods}

The investigation was conducted at the Laboratories of Porous Media, Particulate Systems and Biochemical Engineering at the Chemical Engineering Academic Unit in the Science and Technology Center of the Universidade Federal de Campina Grande-Paraíba state.

\subsection{Obtaining a Raw Material}

Fresh cashew apple bagasse was used, obtained from FRUTNAT, a fruit juice production company located in the city of Campina Grande/Paraiba/Brazil.

\subsection{Preparation of Raw Material}

The cashew apple bagasse was washed twice in water at $60^{\circ} \mathrm{C}$, and then water at room temperature until reaching ${ }^{\circ}$ Brix 0 . After washing, it was placed into aluminum trays and dried in an air circulating oven at $55^{\circ} \mathrm{C}$ for 48 hours, depending (Figures 1(a)-(c)). It was then immediately ground in a knife mill, sieved through 40 mesh sieves and stored in polypropylene bags for subsequent use.

\subsection{Acid Prehydrolysis of Cashew Apple Bagasse}

Dried cashew residue was treated with a dilute acid solution (95\% pure sulfuric acid-VETEC/PA), and prehydrolysis liquor was obtained at $105^{\circ} \mathrm{C}$ for $1 \mathrm{~h}$ in a pressurized $700 \mathrm{~mL}$ stainless steel reactor, using a weight ratio of 1:6 (100 g of sample/600 $\mathrm{g}$ of $\mathrm{H}_{2} \mathrm{SO}_{4}$ at $\left.3 \% \mathrm{v} / \mathrm{v}\right)$.

\subsection{Characterization of Cashew Apple Bagasse: Physicochemical Analysis}

Samples of cashew bagasse dry and prehydrolysis were taken to be its characterization, which was to analyze (moisture, $\mathrm{pH}$, soluble solids, reducing sugars, cellulose, hemicellulose and lignin). Table 1 gives the references of the methodologies used for physicochemical characterization.

\subsection{Characterization of Prehydrolysis Liquor}

Levels of sugars and furan compounds (HMF and Furfural) were determined by high performance liquid chromotography (HPLC) equipped with a ProStar 210 pump (Varian); Manual injector with a $20 \mu \mathrm{L}$ loop; ProStar 356 refractive index detector (Varian) and 284 $\mathrm{nm}$ UV-visible (aldehydes); Hi-Plex $\mathrm{H}$ stainless steel analytical column (300 mm $\times 7.7 \mathrm{~mm}$; Varian), applying the following operating conditions: Column temperature of $40^{\circ} \mathrm{C}$; Mobile phase: $0.005 \mathrm{M} \mathrm{H}_{2} \mathrm{SO}_{4}$ with a flow rate of $0.6 \mathrm{~mL} / \mathrm{min}$; Analysis time: 15 and 60 minutes for

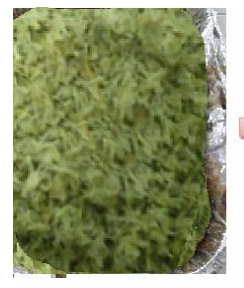

(a)

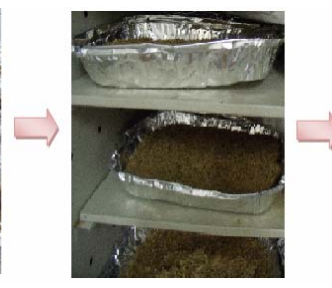

(b)

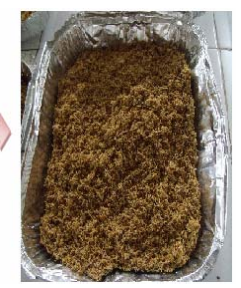

(c)
Figure 1. Cashew apple bagasse: (a) In nature; (b) Drying at $55^{\circ} \mathrm{C}$; (c) Dry.

Table 1. Methods used in the characterization of cashew apple bagasse.

\begin{tabular}{cc}
\hline Parameters Analyzed & Methodology \\
\hline Moisture & {$[13]$} \\
$\mathrm{pH}$ & {$[13]$} \\
Soluble Solids & {$[13]$} \\
Cellulose & {$[14]$} \\
Lignin & {$[14]$} \\
Hemicellulose & {$[14]$} \\
Reducing Sugars & {$[15]$} \\
\hline
\end{tabular}


sugar and aldehyde content, respectively. Internal standard solution for sugars: glucose, xylose, arabinose and sucrose (Sigma 99.99\% HPLC grade), congeners 5-hydroxymethylfurfural-HMF (Aldrich 99.98\%) and furfural (Vetec 99.9 UV/HPLC) were used to quantify the components of liquor.

\section{Results and Discussion}

The physicochemical characterization of cashew bagasse dry and prehydrolyzed shown in Table 2, aims to analyze its composition with respect to nutrient content and for future comparison with the bagasse hydrolyzate.

According to the results shown in Table $\mathbf{1}$ shows that the analysis of dry bagasse resulted in $9.29 \% \pm 0.07 \%$ moisture, however, [16] analyzing the cashew stalk residue dried in a vacuum oven at $65^{\circ} \mathrm{C}$ found $6.99 \%$ moisture. For the analysis of the $\mathrm{pH}$ value of $4.23 \pm 0.01$ was found no significant difference with the values reported by $[16,17]$ at $\mathrm{pH} 4.01$ and 4.52 . For soluble solids was found to be the result of 0 , this is because the pulp was well washed to remove the remaining sugar prior to drying. Now for the AR value was higher than that reported by [18] who studied the efficiency of solvents in the extractives content in pulp of the cashew apple, finding the dry bagasse at $55^{\circ} \mathrm{C}$ the value $0.31 \%$.

Analyzing prehydrolyzed the bagasse it is found that the values of moisture, $\mathrm{pH}$, Brix and AR found for dry pomace cashew are similar to those found in [19] to study the acid hydrolysis of bagasse from the stalk of the cashew, which was reported at 14.51\% moisture, pH 1.77 and $0.10 \%$ of ${ }^{\circ}$ Brix.

A comparison of the chemical composition of dry bagasse cashew pre-treated is shown in Table 3.

In terms of cellulose, hemicellulose and lignin, the pulp of the cashew apple dry values were similar to that found by [8] $19.21 \% \pm 0.35 \%, 12.05 \% \pm 0.37 \%$ and $38.11 \% \pm$

Table 2. Physicochemical characterization of the cashew apple bagasse in natura and after pretreatment.

\begin{tabular}{ccc}
\hline $\begin{array}{c}\text { Parameters } \\
\text { analyzed }\end{array}$ & $\begin{array}{c}\text { Cashew } \\
\text { bagasse dry }\end{array}$ & $\begin{array}{c}\text { Bagasse of cashew } \\
\text { prehydrolyzed }\end{array}$ \\
\hline Moisture (\%) & $9.29 \pm 0.07$ & $23.85 \pm 0.05$ \\
pH & $4.23 \pm 0.01$ & $1.70 \pm 0.04$ \\
Soluble solids ( ${ }^{\circ}$ Brix) & $0.00 \pm 0.00$ & $0.00 \pm 0.00$ \\
Reducing Sugars (\%) & $0.56 \pm 0.02$ & $1.80 \pm 0.08$ \\
\hline
\end{tabular}

Table 3. Comparison between the chemical composition of dried and crushed cashew pretreated.

\begin{tabular}{ccc}
\hline Parameters analyzed & $\begin{array}{c}\text { Cashew } \\
\text { bagasse dry }\end{array}$ & $\begin{array}{c}\text { Bagasse of cashew } \\
\text { prehydrolyzed }\end{array}$ \\
\hline Cellulose (\%) & $18.31 \pm 0.07$ & $31.50 \pm 0.02$ \\
Hemicellulose (\%) & $27.18 \pm 0.01$ & $19.30 \pm 0.09$ \\
Lignin (\%) & $23.91 \pm 0.02$ & $32.21 \pm 0.07$ \\
\hline
\end{tabular}

$0.08 \%$ for the cashew apple bagasse in nature, [20] $38.4 \%, 10.2 \%$ and $2.8 \%$ for soybean hulls, however, [21] studied the same residue found $36 \%, 12.5 \%$ and $18.2 \%$.

It was observed for wheat straw 31, 26 and 24\%, respectively [22]. The values related to lignin were higher than those found by different authors. As can be seen the cashew bagasse dry compared to other residues mentioned, appears to be quite promising for bioconversion products of high added value such as ethanol.

Bagasse from cashew stalk when subjected to pre-hydrolysis with dilute acid changes most of the hemicellulose fraction monosaccharides by hydrolysis (xylose, arabinose, and others). Consequently, the pulp prehydrolyzed has a browning in relation to the dry material due to the formation of degradation products of carbohydrates under acid catalysis [23] as shown in Figure 2(b). It can be seen in Table 3, values for cellulose, hemicellulose and lignin. Compared to the straw marabout 39.5\%, 15.9\% and 31.6\% of cellulose, hemicellulose and lignin, respectively [24] can be observed that the amount of pulp was higher, however, hemicellulose and lignin were similar.

As can be seen in Table 4, the pre-hydrolysis with dilute acid not only solubilizing hemicellulose, but also has the power to convert it into fermentable sugars, the resulting liquor is composed of sugars (glucose, xylose and arabinose), making it an important residue which can be used for producing ethanol, as shown in Figure 3 as a percentage.

\section{Conclusion}

Depending on the results presented here, we can conclude

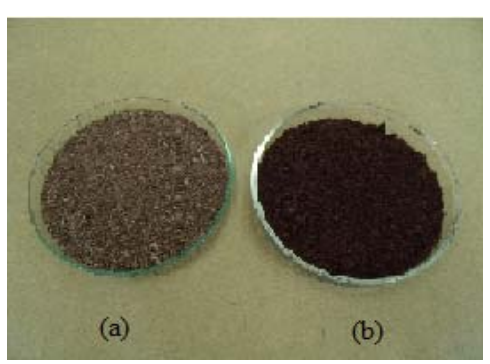

Figure 2. Peduncle of cashew bagasse (a) dry and (b) prehydrolyzed.

Table 4. Concentration (mg/L) and sugar compounds toxic liquor bagasse prehydrolyzed of the cashew apple.

\begin{tabular}{cc}
\hline Component & Content $(\mathrm{mg} / \mathrm{L})$ \\
\hline Glucose & 1758.66 \\
Xylose & 5458.70 \\
Arabinose & 7640.72 \\
Acetic acid & 5.66 \\
HMF & 49.17 \\
Furfural & 0.04 \\
\hline
\end{tabular}




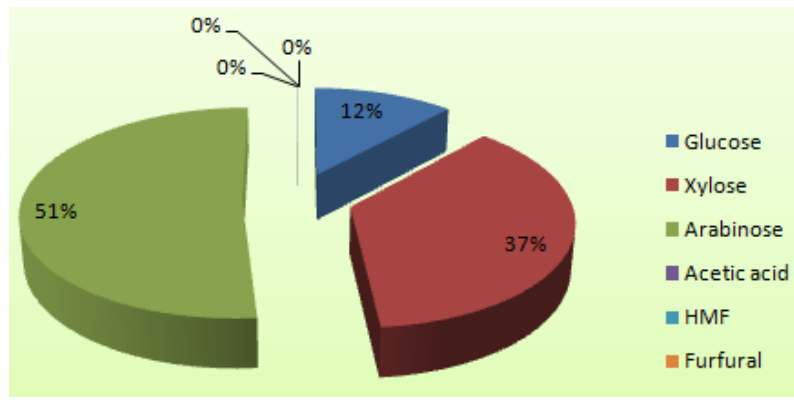

Figure 3. Percentage of sugar in the liquor prehydrolyzed bagasse peduncle of cashew.

that the cashew bagasse biomass has great potential for bioprocess after prehydrolysis, is a promising raw material for bioethanol production, with $12 \%$ of hexoses, and $88 \%$ pentoses.

\section{Acknowledgements}

The authors would like to express thanks to Their Brazilian agencies MCT/CNPq/CTBio for financial support through the Notice MCT/CNPq/CTAgro/CTBio No. 39/ 2007-Vanguard Technologies for the Production of Ethanol and Biodiesel (Case No. 552815/2007-1). CNPq for doctoral fellowships and undergraduate research.

\section{REFERENCES}

[1] C. Piccolo and F. Bezzo, "A Techno-Economic Comparison between Two Technologies for Bioethanol Production from Lignocellulose,” Biomass and Bioenergy, Vol. 33, No. 3, 2009, pp. 478-491. doi:10.1016/j.biombioe.2008.08.008

[2] M. E. Himmel, S. Y. Ding, D. K. Johnson, W. S. Adney, M. R. Nimlos, J. W. Brady and T. D. Foust, "Biomass Recalcitrance: Engineering Plants and Enzymes for Biofuels Production,” Science, Vol. 315, No. 5813, 2007, pp. 804-807. doi:10.1126/science.1137016

[3] International Energy Agency (IEA), “Bioenergy: Potential Contribution of Bioenergy to the World's Future Energy Demand,” Report No. ExCo:2, IEA Bioenergy, Whakarewarewa, 2007.

[4] E. Wit and J. McClure, "Statistics for Microarrays: Design, Analysis, and Inference,” 5th Edition, John Wiley \& Sons, Ltd., Chichester, 2004.

[5] L. A. B. Cortez, "Bioetanol de Cana-de-Açúcar: P\&D Para Produtividade e Sustentabilidade,” Blucher, 2010.

[6] Y. I. Zheng, Z. Pan, R. Zhang and D. Wang, "Enzymatic Saccharization of Dilute Acid Pretreated Saline Crops for Fermentable Sugar Production,” Applied Energy, Vol. 86, No. 11, 2009, pp. 2459-2465. doi:10.1016/j.apenergy.2009.03.012

[7] V. M. P. Rocha, H. T. S. Rodrigues, M. M. V. Melo, L. R. B. Gonçalves and G. R. Macedo, "Cashew Apple Bagasse as a Source of Sugars for Ethanol Production by Kluyveromyces Marxianus CE025,” Journal of Industrial
Microbiology \& Biotechnology, Vol. 38, No. 8, 2011, pp. 1099-1107. doi:10.1007/s10295-010-0889-0

[8] V. M. P. Rocha, H. T. S. Rodrigues, G. R. Macedo and L. R. B. Gonçalves, "Enzymatic Hydrolysis and Fermentation of Pretreated Cashew Apple Bagasse with Alkali and Diluted Sulfuric Acid for Bioethanol Production,” Applied Biochemistry and Biotechnology, Vol. 155, No. 1-3, 2009, pp. 104-114. doi:10.1007/s12010-008-8432-8

[9] H. T. S. Rodrigues, V. M. P. Rocha, G. R. Macedo and L. R. B. Gonçalves, "Ethanol Production from Cashew Apple Bagasse: Improvement of Enzymatic Hydrolysis by Microwave-Assisted Alkali Pretreatment,” Applied Biochemistry and Biotechnology, Vol. 164, No. 6, 2011, pp. 929-943. doi:10.1007/s12010-011-9185-3

[10] A. M. Pacheco, D. R. Gondim and L. R. B. Gonçalves, "Ethanol Production by Fermentation Using Immobilized Cells of Saccharomyces cerevisiae in Cashew Apple Bagasse," Applied Biochemistry and Biotechnology, Vol. 16, No. 1-8, 2010, pp. 209-217. doi:10.1007/s12010-009-8781-y

[11] Y. Sun and J. J. Cheng, "Dilute Acid Pretreatment of Rye Straw and Bermudagrass for Ethanol Production,” Bioresource Technology, Vol. 96, No. 14, 2005, pp. 1599-1606. doi:10.1016/j.biortech.2004.12.022

[12] E. Palmqvist and B. Hahn-Hägerdal, "Fermentation of Lignocellulosic Hydrolysates II: Inhibitors and Mechanisms of Inhibition,” Bioresource Technology, Vol. 74, No. 1, 2000, pp. 25-33. doi:10.1016/S0960-8524(99)00161-3

[13] BRASIL, "Métodos Físico-Químicos para Análises de Alimentos/Ministério da Saúde,” Instituto Adolfo Lutz, 2005.

[14] TAPPI-Technical Association of the Pulp and Paper Industry, "Official Test Methods (OM), Provisional Test Methods (PM) and Useful Test Methods (UM)," One Dunwoody Park, Atlanta, 2010

[15] NREL—National Renewable Energy Laboratory, "Determination of Sugars, Byproducts, and Degradation Products in Liquid Fraction Process Samples,” Technical Report, Laboratory Analytical Procedure (LAP), Golden, 2008.

[16] A. M .A. Uchoa, J. M. C. Costa, G. A. Maia, E. M. C. Silva, A. F. F. U. Carvalho and T. R. Meira, "Physicochemical Parameters, Fiber Content and Gross Food Powders Obtained Food Waste Fruits," Food and Nutrition Security, Vol. 15, 2008, pp. 58-65. (In Portuguese)

[17] M. F. O Matias, E. L. Oliveira, E. G. Guedes and M. M. A. Magalhães, "Use of Fibres Obtained from the Cashew (Anacardium Ocidentale, L) and Guava (Psidium Guayava) Fruits for Enrichment of Food Products," Brazilian Archives of Biology and Technology, Curitiba, Vol. 48, Special Issue, 2005, pp. 143-150. doi:10.1590/S1516-89132005000400018

[18] E Lima, F. C. S. Lima, F. L. H. Silva, J. M. S. Neto and A. S. Silva, "Reviews of Pretreatment for Delignification of the Cashew Apple Pomace for Subsequent Saccharification Process,” In: XVIII Simpósio Nacional de Bioprocessos, Universidade de Caxias do Sul, 2011, pp. 1-6. (In Portuguese) 
[19] J. M. Silva Neto, F. L. H. Silva, E. E Lima and F. C. S. Lima, "Acid Hydrolysis of Bagasse Peduncle of Cashew," In: XVIII Simpósio Nacional de Bioprocessos, Universidade de Caxias do Sul, 2011, pp. 1-6. (In Portuguese)

[20] J. R. Mielenz, J. S. Bardsley and C. E. Wyman, "Fermentation of Soybean Hulls to Ethanol While Preserving Protein Value,” Bioresource Technology, Vol. 100, No. 14, 2009, pp. 3532-3539. doi:10.1016/j.biortech.2009.02.044

[21] D. Y. Corredor, X. S. Sun, J. M. Salazar, K. L. Hohn and D. Wang, "Enzymatic Hydrolysis of Soybean Hulls Using Dilute Acid and Modified Steam-Explosion Pretreatments," Journal of Biobased Materials and Bioenergy, Vol. 2, No. 1, 2008, pp. 1-8. doi:10.1166/jbmb.2008.201

[22] L. Canilha, W. Carvalho and J. B. A Silva, "Xylitol Bioproduction from Wheat Straw: Hemicellulose Hydrolysis and Hydrolizate Fermentation," Journal of the Science of Food and Agriculture, Vol. 86, No. 9, 2006, pp. 13711376. doi:10.1002/jsfa.2524

[23] M. O. Petersen, J. Larsen and M. H. Thomsen, “Optimization of Hydrothermal Pretreatment of Wheat Straw for Production of Bioethanol at Low Water Consumption without Addition of Chemicals,” Biomass and Bioenergy, Vol. 33, No. 5, 2009, pp. 834-840. doi:10.1016/j.biombioe.2009.01.004

[24] V. P. Soudham, D. R. Odriguez, G. J. M. Rocha, M. J. Taherzadeh and C. Martin, “ Acetosolv Delignification of Marabou (Dichrostachys Cinerea) Wood with and without Acid Prehydrolysis,” Forestry Studies in China, Vol. 13, No. 1, 2011, pp. 64-70. doi:10.1007/s11632-011-0106-X 